is very large compared to the number of studies of Costa Rica, for example.

The advantages of the approach I'm outlining are the following:

(1) The range of theoretical/conceptual and institutional topics is sufficiently narrow so that theoretical issues can be given the depth of treatment they deserve and so that students can go with the professor into the degree of depth that enables them to appreciate how we become intellectually excited. That intellectual excitement, I know from experience, tends to be transferred to the students themselves. The complexity and subtlety of a subject are better conveyed in this way than in a couple of 50-minute lectures.

(2) At the same time, even though a single question might be the focus of such a course, the range of arguments used to answer that question can and should include examples from the major theoretical approaches of comparative politics. Students thus can get exposure to political culture arguments, explanations that emphasize political structure and the autonomy of the state, rational choice perspectives, and arguments that stress socio- economic determinants of political action. Politics can be a dependent or an independent variable.

(3) Students get to learn not how abstract frameworks are built but how arguments are constructed by social scientists. Developing the capacity to create a sustained argument about an important conceptual theme and then applying empirical material to it ought to be one of our goals as educators of undergraduates. Whether our students go on to be social scientists or to become involved in politics or government service or go into business, they need this capacity for writing a lengthy argument and marshalling empirical evidence to support it. Reading case studies is a good way to see how such arguments are made.

(4) These topically oriented introductory courses, if the topics are chosen with any care, are about intrinsically interesting material. I think these courses can serve much better as the kind of hooks we'd like to have available to bring students into the study of comparative politics.

(5) As I mentioned earlier, most case studies available are actually about major foreign coun- tries, so to a significant degree the civic education function of the introductory comparative course can still be achieved, but more as a fortuitous than a planned result. The United States, as either a typical case or an exceptional case, can be used effectively as a case too. I recommend that departments create two to four such courses that can serve to meet a comparative politics requirement for the political science major. These courses ought to be on intrinsically interesting topics that encourage students to take more in the field while at the same time introducing them to the comparative method and to empirical political science outside the American context.

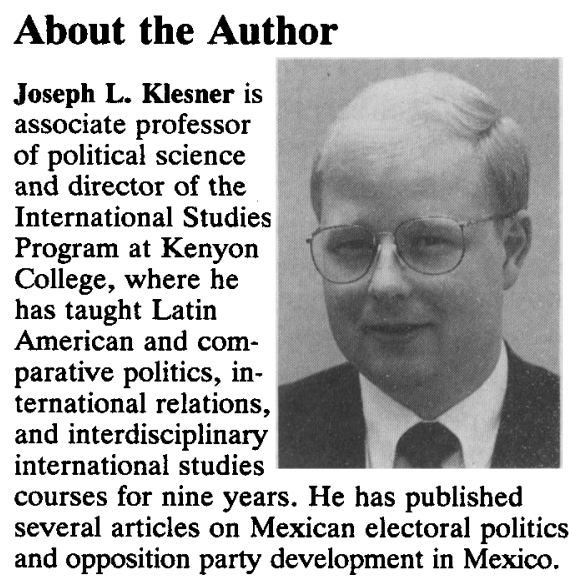

\title{
The Parable of the Frog
}

\section{Charles Hauss, George Mason University}

In discussing the teaching of introductory courses in comparative politics with colleagues, I am frequently reminded of a metaphor that some management consultants use: the parable of the frog (Senge 1990, esp. 22-25). Management consultants use the parable to get employees to turn their corporation into a "learning organization." Such a group is able to assimilate what is going on around it-espe- cially changing circumstances - and react effectively to its environment. It seems that if a frog is dropped into boiling water, it will do everything possible to scramble out and not be cooked alive. On the other hand, if you gently drop a frog into a pot of water at room temperature, it will calmly stay put. Then, if you gradually turn up the heat, the frog will still stay happily in the water, getting groggier and groggier until the water reaches the boiling point and kills it. Those consultants tell us that far too many organizations are a lot like that second hypothetical frog.

It is my thesis that most of us who teach introductory comparative politics are too. A recent compilation of syllabi for introductory comparative politics courses reveals a subfield with a remarkable diversity in the way those courses 
are structured (Wilson 1991). Courses cover widely different concepts and places. Some are organized topically, some by country. Some retain the Eurocentric bias of traditional political science, some the supposedly politically correct focus on the less developed countries where most of the world's population lives. Some rely on cutting edge research, some on conventional and traditional textbooks. Common to most of them, however, is a reliance on a set of ideas, concepts, and theories of comparative politics that date back to the 1960 s and that cannot readily help account for the dramatic changes that have occurred since then.

Our "water" is nowhere near the boiling point, and, unlike the second frog, we have not failed completely in reacting to the changes in our environment. Nonetheless, I will argue here that there are two trends that have dramatically altered the political and pedagogical environments in which we teach and which, in turn, call for at least four changes in the way the introductory course is taught.

First, the world has changed. The cold war is over. The world is more interdependent. Economic and environmental issues matter a lot more. Issues of race, gender, sexual preference, and multiculturalism are now squarely on the political agenda.

The second change probably requires more exploration. Our students are different. The typical first-year student who takes introductory comparative politics this academic year was born in 1977. The issues that sparked the breakthroughs in comparative politics a generation ago are ancient history to them. So, too, is the cold war, which only the most precocious of them will remember. Theirs is also the first generation raised on MTV.

Many of us academics tend to look on this generation of students negatively. They know less. They have a shorter attention span and demand more immediate gratification in every aspect of their lives, including their studies. On the other hand, they are better able than most people of their parents' generation to see that the changes sweeping the world in the last few years have made political life more interdependent and qualitatively different from anything ever experienced in the past (Hauss 1990).

In sum, whether we like it or not, our students today are very different from those of a generation ago. Hence, our approaches to teaching them have to change.

Our courses should be politically relevant. A pair of curious misconceptions developed during the behavioral revolution of the 1950 s and 1960s. Our scholarship and teaching were supposed to be objective and value-free. Similarly, focusing on current issues came to be seen as journalistic, therefore keeping us from being scientific and using evidence in the quest for generally applicable and parsimonious theory.

\section{We comparativists are in an ideal position to use current and controversial} issues to address diversity themes in a rather complex, nontrivial, or
nondogmatic nature.

In fact, the comparativists who played such an important role in launching the behavioral revolution did so by dealing with current, politically relevant issues. The issues they chose to focus on, such as the link between culture and democracy or the state and development, were both of the utmost importance at the time and fraught with ideological overtones. Moreover, while focusing on the current events of the 1950 s and 1960s, these scholars developed some of the most robust (and also at times controversial) theories the subfield has ever seen.

Comparativists in the 1990s can do the same thing. One obvious area in which we have a lot to contribute as comparativists is in adding to the "diversity" of what students learn. Even though I am a Europeanist, I strongly support the view that comparative courses have not done enough with diversity. Ours is a world in which the overwhelming majority of the people are not white. Ours is a world, too, in which the new arenas of conflict, such as the one that led to the Gulf War, will require any educated person to know about "the south." Ours is a world in which the overlapping issues of gender, race, economic growth and equity, and the environment are taking on new importance.

We comparativists are in an ideal position to use current and controversial issues to address diversity themes in a rather complex, nontrivial, or nondogmatic nature. Take, for example, a section in an introductory course on Nigeria. One cannot teach about Nigeria without exploring the relationship between imperialism, racism, and the instability and slow growth that have plagued Nigeria. Those issues, unfortunately, often remain abstract intellectual concepts, no more meaningful or vibrant for our students than the second law of thermodynamics.

However, by building a discussion on Nigeria from two provocative articles from one four-day stretch of the New York Times, one can deepen student understanding of those concepts (Noble 1992a, b). The first discusses the widespread ethnic violence of the previous few months, including that between two of the smaller groups, the Jukun and the Tivs. The second profiles Chief Moshood Kahimawo Abiola, a close confidant of then president Ibrahim Babangida who has demanded that former slave-owning nations pay reparations to the African countries from which the slaves originally came. It should be noted that this is the same Abiola whose apparent election as president in 1993 was annulled by the same Babangida.

The articles allow the professor to do at least two things. First, both can be used to show students how much racism and imperialism of earlier centuries shape life in Nigeria and other African countries today. Second, they allow students to see some of the complexities and 
disagreements over these sensitive issues.

Raising such contemporary and controversial issues is not easy. Focusing on current and controversial issues poses at least two pedagogical problems. First, it is intellectually hard to do. Relatively little material is available on some of the subjects, especially in the texts. However, there are places one can turn. The APSA (Pempel, et al. 1992), for instance, has developed a series of articles to help instructors include Japan in the introductory course. Journalistic sources can provide the instructor with thought-provoking examples to use in class. It is also vitally important for students and teachers to stay current. I require my students to read the daily New York Times or The Christian Science Monitor.

Second, one also cannot avoid the touchy issue of professorial bias and what it does to classroom climate and grading, among other things. I have chosen to wear my ideological shirt on my sleeves and worked to create an environment in which students feel comfortable taking me on.

Use the United States as a frame of reference. I have also found it useful to include the American experience, especially in helping students see difficult and/or controversial points. Students are going to compare what they learn with the United States whether we like it or not. Using the United States as a frame of reference, however, can be doubly dangerous if it is not addressed directly in the course. First, students do not know very much about American politics or history. Second, at the beginning of the semester, most students are inclined to assume that what happens in their own country is somehow typical and/or the best.

As with taking on controversial issues, there is no single way to bring in the United States. There do, however, seem to be two important ways to use the United States in the introductory course. First, it is important for students to see that in many important respects the United States is the exception rather than the rule, even in com- parison with other industrialized liberal democracies. Second, using the United States as a frame of reference is particularly important when we introduce difficult concepts such as a comparison of parliamentary and presidential systems.

Use international issues explicitly as independent variables. One cannot explore any major economic or environmental policy issue in any of the countries we have taught about without bringing external factors in. Even though our focus is the relationship between state and society, one of the key overarching themes in the course must be that the power of states and their citizens have both declined, because international constraints have limited their ability to shape their own

\section{Focusing on current and} controversial issues

poses at least two

pedagogical problems. First, it is intellectually hard to do. . . . Second, one also cannot avoid the touchy issue of professional bias...

destinies. Students of international political economy were probably the first to show us that a decade or more ago. It is perhaps most evident and important in explaining the collapse of the Soviet Union.

Incorporating international issues has one of the same problems as dealing with controversial ones. It is not easy. Generally speaking, comparativists do not have the intellectual or methodological tools to systematically incorporate most international constraints. There is also a shortage of material in the available literature, especially for those of us who are forced to rely on conventional sources because we have to teach about countries that lie outside our field(s) of expertise. Still, there is a simple bot- tom line here. The conventional paradigms of comparative politics do not give much attention to these factors. In the 1960s one could plausibly argue that they were not all that important. Now that is clearly no longer the case, and our teaching and scholarship must reflect that reality.

Change the way we use theory. So far, this paper has advocated adding new concepts to what is already a reasonably rich set of ideas and theoretical insights that have dominated the subfield for a generation. My final point explores an alternative way to use that theory and is drawn not from political science, but from the literature on how undergraduates learn. Scholars in education who have studied how students learn suggest that undergraduates have trouble dealing with abstract or general theory, especially when it involves the kind of complex, nuanced arguments typical of comparative politics (Piaget 1965; Perry 1970; Kohlberg 1984; Gilligan 1982).

They point, in particular, to problems students have with theoretical concerns. Younger college students, especially, have trouble thinking deductively. To the degree that they think theoretically, it tends to be in "either/or" terms. Even seniors at elite institutions have trouble coping with arguments that have multiple and interrelated causes.

The canons of scientific orthodoxy appropriately see our task as the development of theory. The best way to do that, in general, is to start with a theory, to confront it with data, and to reformulate the theory on the basis of the discrepancies uncovered in field research. As a result, in our teaching, we tend to start by presenting theoretical concerns to undergraduates, especially the first- and second-year students in introductory courses. But the scholarship on learning suggests that undergraduates learn best inductively. Undergraduates see concepts as rigid and absolute when presented at the beginning of the course. The subtlety, complexity, and nuances mentioned above are easier for them to explore if 
they have an empirical base to work with.

That means focusing on two things. First, written assignments have to serve a dual purpose. Not only do they have to show the student's mastery (or lack thereof) of the substantive material, they have to be designed so that students can compare two or three examples and begin to see how one or more of the key concepts in comparative politics helps make sense out of the variation encountered in class and in the readings.

Second, theory and concepts can play an extremely important role at the end of the course. At that point, the student can bring the concept or proposition "to life" by examining it in the light of the substantive material covered during the course. And, because the theoretical and generally applicable material comes near the end, it is what the student is most likely to retain in the months and years after the course ends, particularly those students who never take another comparative politics course again.

Conclusion: On Seeing With New Eyes. Marcel Proust once wrote, " $[t]$ he real voyage of discovery consists not in seeking new lands, but in seeing with new eyes." Helping students "see with new eyes" is the pedagogical challenge facing comparativists.

When I was an undergraduate in the late 1960 s that was easier than it is now. The concepts comparativists had just developed "spoke" to the events unfolding in the world, especially in what we then called the "new nations" of the "developing world."

If the argument of this paper is correct, that connection between the "real" and "academic" worlds is less evident now when, given the way our students have evolved, the need for showing it to them is more important than ever. Again, if this argument is correct, it means we have to blend the issues we have experimented with plus others we have done less with (e.g. gender, political economy) into the traditional core of the subfield.

\section{References}

Gilligan, Carol. 1982. In a Different Voice: Psychological Theory and Women's Development. Cambridge: Harvard University Press.

Hauss, Charles. 1990. "The End of the Cold War: Challenges for Peace Education." Peace and Change 15:223-39.

Kohlberg, Lewis. 1984. Essays on Moral Development: The Psychology of Moral Development. Vol. 2. New York: Harper and Row.
Noble, Kenneth B. 1992a. "Dawn Brings Death: One More Day of Ethnic War." New York Times. August 5:A3. _. 1992b. "Nations in Slave Trade Urged to Repay Africa." New York Times. August 10:A2.

Pempel, T. J., Shigeko N. Fukai, Haruhiro Fukui, Stephen J. Anderson, Ellis S. Krauss, and Roger W. Bowen. 1992. "Introducing Japan into the Comparative Politics Curriculum." PS: Political Science and Politics 25:5-73.

Perry, W. G. 1970. Forms of Intellectual and Ethical Development in College Years: A Scheme. New York: Holt, Rinehart, and Winston.

Piaget, Jean. 1965. The Moral Judgment of the Child. New York: Free Press.

Senge, Peter. 1990. The Fifth Discipline: The Art and Practice of the Learning Organization. New York: Doubleday.

Wilson, Frank L. 1991. Comparative Government and Politics. Washington DC: Political Science Course Syllabi Collection, American Political Science Association.

\begin{abstract}
About the Author
Charles "Chip" Hauss teaches comparative politics and international relations at George Mason University. He has long been active in the Advanced Placement program as a test reader and question writer. $\mathrm{He}$ is the author of four books, including a textbook, Comparative Politics: Domestic Responses to Global Challenges (West Publishing), and is finishing an introductory international relations text. He will spend 1995-97 in Britain working on a book on racism and politics in Europe and North America.
\end{abstract}

\title{
On Reading: Strategies for Students*
}

\author{
Anthony Daley, Wesleyan University
}

Why should you read an essay on reading? Good question. What do you do before you write? You surely know what you must do first. You must think. You sit down at your desk to write an essay. Why is it such an ordeal? You must think.

Let's step back a bit. Think about your attitudes toward reading. Do you like to read? What do you enjoy reading? Or not enjoy reading? Why do you have trouble reading certain materials, such as the readings for your comparative politics course? Why do you find
National Inquirer easier? Perhaps you need to look up words from that social science reading in a dictionary. Good. The only way to increase your vocabulary and avoid perpetual recourse to a dictionary is to find out what those difficult words mean.

Reading is fun for its own sake because it engages our imagination. It can be as racy and as compelling as we allow it. We read, however, for more than simple enjoyment.

In the university, we read to accumulate raw materials, to sharpen our analytical capabilities, and to develop our expressive skills. The first reason entails borrowing information or data for an argument we might make later. The second encourages us to develop our own ideas, while the third helps us express our ideas more persuasively. Reading and writing empower us through active learning: the process of self-expression helps us forge connections among superficially disparate observations.

Before you sit down to write an essay, you need to know something about the subject. When students come to my office in search of pa- 